\title{
İslami Perspektifte Ekonomi Psikolojisi
}

\section{Dr. Ahmet EFE}

\section{ÖZ}

Sürdürülebilir ekonomik kalkınma için gerekli olan teknolojik üretkenlik, kaynak verimliliği, ileri teknoloji bilgisi, ortak çalışma kültürü, işbölümü ve süreç optimizasyonu gibi temel yapıların politika ve kurumsal düzeyde tesis edilmesi büyük öneme sahiptir. Ancak, etik değerlere, diğer insan ve canlıların hukuklarına saygı, yardımda bulunma, toplumsal düzene uyma ve bilinçli olarak insanlığın yararına çalışma gibi temel ilkelerin uygulanabilirliği ve insanların psikolojik olarak bu ilkelere istekli bir şekilde kabullenerek uygulamaları sürdürülebilir kalkınma kadar toplumsal refah, insan huzuru ve mutluluk açısından çok daha önemlidir. Çalışmamızda, toplumsal huzur ve insanlığın topyekûn gelişimini sağlayacak bir etik değerler bütünü sunabilen İslam dininin şahsi, sosyal ve iktisadi hayatı düzenleyen temel ilkelerinin uygulanabilirliği Risale-i Nur tefsiri referansıyla bazı örnekler üzerinden araştırılmaktadır. Temel argümanımız, bunun maddi politika ve kurumsal tedbirlerle değil güçlü iman ve samimi kabuller ile doğrudan ilgili olmasından dolayı psikolojik temellerinin ihmal edilmemesi gerektiği ekonomik, dini ve psikolojik analizler yapılarak değerlendirilmektedir.

Anahtar kelimeler: İslam ekonomisi, davranış ekonomisi, ekonomi psikolojisi, duygusal ekonomi

\section{Phycology of Economics from the Islamic Perspective}

\begin{abstract}
It is of crucial importance that the main foundational requirements for a sustainable economic development which are technological productivity, resource efficiency, high tech know-how, cooperative business culture, division of labor and process optimization be set up by policies and institutional implementations. However, applicability of and willingness to basic principles such as ethical values, respect for rights of all creatures and freedom, helping to the ones in basic needs, complying with civil rules and working for goodness of humanity are important not only for sustainable economic development but also for welfare, human happiness and general weal. In this study, in order to define availability and applicability of basic principles of Islam that is said to have potentiality to provide welfare and comprehensive development by regulating psychological, social and economic relations, are investigated with the reference of Risale-i Nur, one of the main contemporary Koranic commentaries. Our main argument is that İslam has such principles and via research on psychological, economics and religion it is found to be possible by a firm belief rather than policies and institutional measures and therefore the psychological aspects have to be taken into consideration in the equation.

Key words: İslamic Economics, Behavioral Economics, Phycology of Economy, Emotional Economy




\section{GIRIŞ}

Bir sosyal bilim olarak ekonomi, insanların ve toplumların sahip oldukları sınırlı kaynaklarıyla onların sürekli gelişen sınırsız ihtiyaçlarını karşılama bilimi veya ekonomik tercihleri analiz ederek belirli teori ve kavramlar ışı̆̆ında değerlendirme olarak tanımlanmaktadır. İnsan ihtiyaçları ve tercihleri kuşkusuz insanın içinde bulunduğu psikolojik ruh haline göre değişkenlik gösterebilmektedir. Bu nedenle ekonomik tercihlerin piyasaya yansıtılmasında davranışların arkasında bilinç düzeyi, algılar, inanışlar ve kültürel değerler de etkili olduğundan salt açıdan ekonomik fayda veya objektif kullanım/değişim değerleri ile iktisadı açıklayabilmek olanaklı değildir. Çünkü iktisat, pozitif olduğu kadar normatif ve objektif olduğu kadar sübjektif parametrelerin de dikkate alınarak değerlendirildiği bir bilim dalıdır. Bu noktada ekonominin psikoloji ile kesişimi kaçınılmaz olmaktadır. Bu nedenle de ekonominin psikolojik temelleri, ekonomik adamın tercihleri, algısı, değerleri ve davranışlarını tetikleyen bilişsel etkenler çerçevesinde dikkate almak önem arz etmektedir.

Bağımsız bir bilimsel disiplin olarak İslam ekonomisi çalışmaları da, özellikle 1980 yıllarından sonra artmaya başlamış ve bu alanda akademik çalışmalar hız kazanmıştır. İslam'ın inancı temel almasından dolayı modern iktisat yaklaşımlarıyla tam olarak uyuşamadığı, objektif yaklaşımlardan çok sübjektiflik ve pozitivist değerlendirmelerden ziyade normatiflik daha ağır basmakta ve bilimsel disiplin olarak henüz tam olarak kabul görmeyebildiği söylenebilmektedir. Bilimsel disiplin alanında şer'i hukuk yaklaşımları ile birlikte finansman metotları daha ağır bastığından modern iktisat dışında nasıl bir analitik yaklaşım gösterilmesi gerektiği de henüz tam olarak netleşebilmiş değildir. Bu nedenle de öncelikle İslam ekonomisi disiplininin diğer komşu disiplinlerle olan teması ve ilişkilerinin incelemeye konu edilmesi bu anlamda hatırı sayılır bir katkıda bulunacağı düşüncesiyle ekonomi ve psikoloji ile kesişiminde İslam'ın farklı olarak ne tür bir katkı sağlayabildiğinin inceleme konusu olmasında yarar görülmüştür. Bu konuda incelenebilecek pek çok eser içerisinden Risale-i Nur tefsiri özelinde değerlendirmeler yapılması tercih edilmiştir. Bunun nedeni de Risalelerin diğer eserlerde rastlanılmayan üslubu, içeriği ve tarzındaki orijinalliktir. Örneğin İktisat risalesinde modern iktisadi kuramlara benzer analizler yapılmadan ve maddi sermaye birikimleri dikkate alınmadan insan huzuru, saadeti ve lezzeti hem dünya hem de ahiret kazançları açısından ele alınarak her an ölümle yüz yüze bulunabilen insanın en önemli sorununun yok olmaktan ve cehennemden kurtulmak olduğunun altı çizilerek insanın elindeki ömür sermayesinin kıt bir 
kaynak olarak nihayetsiz ihtiyaç içerisinde bulunduğu yokluktan kurtulmak ve saadetli ebedi yaşama kavuşturacak şekilde kullanılması gerekliliği üzerinde değerlendirmeler yapılmaktadır. Dolayısıyla insanın dünya hayatından ziyade ahiret hayatının kazanmasına odaklanırken İslam'ın karakteristik bir yönü olarak dünya hayatının da daha saadetli, mutlu ve lezzetli geçirilebildiği analiz edilecektir.

Kuşkusuz psikoloji veya ruh hali, insanın sadece bireysel davranışlarını değil aynı zamanda, iktisadi kararlarını, yatırım ve tüketim tercihlerini de belirleyen önemli bir etkendir. $\mathrm{Bu}$ bağlamda ekonomi bilimi sosyoloji kadar psikoloji ile de ilişkili olarak kabul edilmektedir. Hatta sosyo-ekonomik psikoloji alanında çalışmalar mevcuttur. Bu konunun İslami boyutunda ne olduğunun irdelenmesi bu çalışmamızın ana konusunu teşkil etmektedir.

Modern iktisat teorisinin sadece dünya hayatıyla ilgili sınırsız ihtiyaçların sınırlı kaynaklarla karşılanabilmesi noktasında analizler yaparken, İslam ekonomisi dünya hayatını değil aynı zamanda ahiret hayatını da dikkate alırken ahiret hayatını dünya hayatına öncülleyen ve dünya hayatını da ahiretin bir tarlası bir mezrası gibi eldeki kaynaklardan birisi olarak değerlendirir. İslami literatürde pek çok kaynak ve yaklaşım mevcuttur. Hepsinin birlikte incelenerek analiz edilmesi bir makale çalışmasına sığdırmak olanaklı değildir. Ancak bunlar içerisinde çağdaş bir yazar olan Said Nursi'nin eserleriyle sınırlı bir inceleme yapılması tercih edilmiştir. Risale-i nur tefsirindeki temel yaklaşım da bu noktada her gün verilmiş olan yirmi dört saatlik ömür de bir kıt sermaye olarak ele alınmakta ancak bu sermaye ile ebedi bir hayatı dünyalar kadar bağlar ve bahçeler kazanma imkânı sunan bir firsat olarak ele alınmaktadır. Sadece fikhi hükümlerin dogmatik bir şekilde uygulanması gerekliliğini savunan bir yaklaşım sergilenmeden akli ve nakli delillerle zamanın gereklerini bağdaştırmasından dolayı ayrı bir önemi haiz olduğu tespit edilmiştir. Orijinal olan bu yaklaşımda elbette insanın kabulleri, ruh hali, düşünce, şuur, iman ve yaklaşımları önem arz etmektedir. Bu nedenle de İslam ekonomisinin psikolojik temellerinin insan psikolojisi üzerinde değerlendirmeler yapan bir Tefsir kapsamında irdelenmesi İslam ekonomisi disiplininin olgunlaşabilmesi açısından önem arz etmektedir.

\section{Metodoloji}

Araştırmamızda betimleyici ve ilişki arayıcı mantıksal analiz metotları kullanılmaktadır. Ayrıca İslam ekonomisi, davranışsal ekonomi ve ekonomi psikolojisi üzerinden de literatür taraması yapılmaktadır. Ebsco veri tabanında yabancı literatür taraması yapılmıştır. Buna göre "islamic 
economics" olarak yapılan aramada 189 adet makale, "behavioural economics" olarak yapilan aramada 2.514 adet makale ve "psychology of economy" olarak yapılan aramada ise 15 adet makele çıkmıştır. Dolayısıyla İslam ekonomisi ile davranış ekonomisi göreceli olarak yeterli düzeyde araştırmaya sahipken ekonomi psikolojisi alanında göreceli olarak yetersiz sayıda literatür bulunduğu söylenebilir. Türkçe literatür araştırması için de "Íslam ekonomisi" olarak yapılan aramada 10 adet makale, "davranışsal ekonomi" olarak yapılan aramada 1 adet makale ve "ekonomi psikolojisi" olarak yapılan aramada ise hiç yayın olmadığı tespit edilmiştir. Dolayısıyla araştırma alanında yeterli düzeyde yayın varken Türkçe literatürde yeterli düzeyde yayın olmadığı görülmektedir. Bu husus da kuşkusuz yaptığımız çalışmanın Türkçe literatüre olan katkısının önemli olduğunu ortaya koymaktadır.

Bu çalışmamızda temel amaç, İslam ekonomisinin psikolojik boyutuna dair detaylı bir çalışma yapmak değildir. Zira bu ancak bir kitap çalışmasına konu edilebilecek düzeyde kapsamlı bir analiz ve değerlendirmeyi gerektirmektedir. Buradaki temel amaç, İslam ekonomisinin psikolojik temellerinin olup olmadığının ortaya konularak bunların modern iktisadın dayandığ batı psikolojisinden nasıl farklılık arz ettiğini bazı örnekler üzerinden göstermektir.

Araştırmamızın temel varsayımı, psikolojik etkilerin insan davranışlarını etkilediğidir. Temel iddiamız da İslami ilkelerin ekonomik hayattaki sorunları çözüm sağlayabilecek düzeyde psikolojik ve davranışsal yetkinliğe sahip olduğudur.

İslam ekonomisi disiplini üzerinde yaptığımız bu araştırmayla ekonominin psikolojik boyutuyla literatüre katkıda bulunmak ve Türkiye'de çıkmış bir dini eser olarak Risale-i Nur'un konuya katkısının olup olmadığının tespit edilmesi gerektiği düşünülmüştür. Buna göre araştırma sorularımız şu şekilde belirlenmiştir:

\section{1. İslam dininin ilkeleri insan davranışlarını yönlendirici olarak psikolojik açıdan analiz} edilebilir mi?

2. Türkiye'de ortaya çıkan çağdaş bir eser olması açısından Risale-i Nur tefsiri İslam ekonomisinin psikolojik temellerini ortaya koyabilme açısından referans alınabilir mi?

Yukarıdaki araştırma sorularına cevap aranırken öncelikle; konu ile ilgili araştırma probleminin ne olduğu İslam ekonomisi disiplinin kuramsal ve kavramsal olarak ne tür sorunları bulunduğu analiz edilerek araştırma problemi yapılandırılmakta; modern ekonominin psikolojik temellerinin olup olmadığı davranışsal ekonomi ile ilgili analizler yapılarak kuramsal 
referansları analiz edilmekte; din kültürü ile ekonomi arasında nasıl bir ilişki olduğu noktasında tespit ve değerlendirmelerde bulunulmakta; İslam ekonomisinin kavramsal ve kuramsal temelleri dini referanslar çerçevesinde değerlendirilmekte ve en son Risale-i Nur tefsirindeki ekonomi ile ilgili değerlendirmelerden hareketle ekonomi psikolojine dolaylı olarak yapılan atıflar davranışları tetikleyen tahkiki gerçek iman üzerinden analizler yapılarak araştırma sorularının cevaplanmasına geçilmektedir.

\section{Araştırma Problemi}

Araştırmamızda, ekonomik davranışların inançtan kaynaklanan nedenlerinin olup olmadığı ve bunun İslami perspektiften psikolojik analizlerle çözümlenmesinin olanaklı olup olmadığı araştırılmaktadır. Bunun nedeni de ekonomik sorunların çözümü için genelde çeşitli politika paketleri ile kurumsal yapılar üzerinde durulurken uygulayıcıların ve etkilenen kesimlerin psikolojilerinin ve davranışlarını etkileyen temel inanç ve kabullerin göz ardı edilmesidir. İnanç ve değerlerin de gerçekten istenilen veya bunların gerektirdikleri maddi sonuçlarının meydana gelmesi de neticede insan psikolojisiyle ilişkilendirilmemesi olanaklı değildir. Bu durum en önemli sorun olarak tespit edilmiştir. Bunun yanı sıra, bazı araştırmacıların da ifade ettiği üzere, Müslümanların maddi olarak geri kalmışlıkları ve aralarında birliğin olmamasının aslında onları arzuladıkları caddede ilerlemelerini sağlayabilecek olan Kuran'ın Dünya görüşünden olmalarıdır (Shittu, 2014, s. 240).

1970 li yıllardan itibaren kapitalizm ve sosyalizmin yıkıcı etkilerini ortadan kaldırabilecek alternatif sistem arayışları kapsamında değerlendirilebilen İslam ekonomisi çalışmaları büyük cesaretle ilerlerken bu çalışmalar Zekât ve evkaf uygulamaları gibi bazı İslami finansman modelleri dışında tam olarak gerçek hayatta uygulama imkanı bulmayarak kitaplara ve makalelere hapsolmuşlardır. İslam ekonomisinin âlimlerle ekonomistler arasındaki iş bölümü, gerçek yaşamda yokluğu, makroekonomi için genel denge modeli eksikliği, şeriatın rolünün belirsizliği, merkez bankalarının İslami finansman uygulama şekilleri gibi temel konulardaki eksiklikleri bilim adamları ve uygulamacılar tarafindan doldurulmak durumundadır (Al-Jarhi, 2013).

İslam ekonomisinin bir bilimsel disiplin olarak geliştirilmesinde ciddi krizler olduğunu gösteren kanıtlar mevcuttur. Bunun temel sebebi ise Müslüman ekonomistlerin çoğunun batı ekonomisi felsefesini sorgulamadan kabul etmelerinde yatmaktadır. Bu nedenle metodolojik 
olarak alt yapıyı oluşturan varsayımlar yanlış olduğundan İslami bakış açısı ve felsefesiyle çatışmaktadır. Bu çatışma henüz iyice bilinir değildir ve çatışan bilgi alanlarındaki bu sorunu çözmeye yönelik çabalar da başarısız olmaktadır (Zaman, 2012, s. 143).

İslam ekonomisi çalışmalarının başarısız olmasının nedeni, modern ekonominin epistemolojik ve sosyo-tarihsel temellerini yani kökündeki meta-ilkeleri başarılı bir şekilde kapatamadan onları İslam'ın normatif pozisyonuna göre dönüştürememesidir. Al-Attas'a göre, bilginin İslamileştirilmesi için modern ekonominin kökünde yer alan felsefi temeller İslam'ın metafizik ve değerbilimsel (axiological) çerçevesine göre kritik bir şekilde ayarlanarak yerleştirilebilmesi gerekir (Jha, 2013, s. 171).

Bazı araştırmacılar ise İslam ekonomisi ile ilgili çalışmalarda stratejik vizyon eksikliği sorunu olduğu tespiti yapılmıştır. Buna göre, teorileştirilme çabalarının metodolojik olarak doğru olmadığı, aslında yapılması gerekenin "islam ekonomi teorisi” değil, "ekonominin İslami teorisi" olduğu iddia edilmiştir. Bunun için de insanın ekonomik davranışının incelenmesi gerektiğinden İslam ekonomisinin bu sorunu çözebilmesi için öncelikle fizik ve matematik gibi pozitif fenlerden boşanarak biyoloji, sosyoloji, psikoloji ve felsefe gibi insan yaşamını konu edinen bilimlerle evlenmesi gerektiği savunulmuştur (Khan, 2013).

Konuyla ilgili eleştiri yapanlardan bazıları çok ileri de gitmişlerdir. Örneğin Sohrab Behdad, İslam ekonomisinin İran'da uygulama teşebbüsleri hakkında bahsederken "İslam ekonomisinin geçerli bir sosyal alternatif oluşturma kabiliyetinden yoksun olduğu açıkça ortadadır” şeklinde ifade kullanmış ve Timur Kuran da benzer şekilde İslam ekonomisinin öz ve içerikten yoksun olduğunu ve İslam ekonomisi çalışmalarının da aslında farklılaştırılmış bir İslam kimliği oluşturma çabaları olduğunu ileri sürmüştür (Zaman, 2012, s. 145).

Müslüman toplumların geri kalmışlıklarının nedenleri üzerine daha pek çok analiz yapılmıştır. Ancak ekonomik sorunların çözümü için genelde çeşitli politika paketleri ile kurumsal yapılar üzerinde durulurken İslam ekonomisinin çözüm sağlama kabiliyetinin göz ardı edilmesi bir sorun olarak ortaya çıkmaktadır. Ekonomide etkili olan beklentiler, "rasyonel beklentiler teorisi” tarafından objektif olarak analiz edilmektedir. Bu analizlerde beklentilerin çevresel koşullar veya suni uygulamalarla biçimlendirilebileceği de kabul edilmektedir. Bu nedenle beklentilerin psikolojik, ekonomik ve dini boyutunun İslam ekonomisi çalışmaları kapsamında çözümlenmesi araştırma problemimiz olarak kabul edilmiştir. 


\section{Modern Ekonominin Psikolojik Temelleri}

Pozitif ekonomi, fayda maksimizasyonuna dayanan bir davranış modelini kullanır. Fakat bu yaklaşım görev ve erdemli davranışın eksikliği noktasında başarısız olmaktadır. Sonuçlar, görevler ve erdemli davranışlar, iş hayatının sürdürülebilirliğinde ciddi etkide bulunmaktadır. Örneğin, doğruluğu ekonomik araştırmalar topluluğu içerisinde aramayı yüceltmek gibi uygulamalar (Wight, 2014).

Din veya din benzeri kavram, düşünce ve paradigmalar ekonomiyi zenginleştirebilir mi? aslında klasik ekonomistlerin istediği gibi bir ahlaki bilim olarak ekonominin yükselmesine katkıda bulunabilirler. En azından gelecek nesillerdeki ekonomistlerin ve finansal uygulayıcıların kendisini sevme veya bireysel çıkarı düşünme gibi motiflerin aynı zamanda diğerlerini de düşünmeyi denklem dışarısına çıkarmasına ihtiyaç olmadığı ve aynı zamanda kişisel çıkara hizmet etmenin insan onuruna veya diğerlerinin kişilik haklarına saygısızlıkta bulunmaya müsaade etmek durumunda olmadığı noktasında daha dikkatli olacaklardır. İnsanlığın birliği, kişiliğin onuru, kişilik hakları, özgürlük ve bireysel tercihe saygı gibi yaratıcı tarafından verilen kritik kavramlarla ilgili olarak bütün dinler tarafından paylaşılan fikirlere dayanan ekonomiye giriş yapılabilmesi için daha çok yol alınması gerekir (Mirakhor, 2014).

Kapitalizm ve bürokrasi ilişkisini dini perspektifle de ele alan sosyolog Max Weber'in "The Protestan Ethic and The Spirit of Capitalizm" isimli kitabının genelinde, dinin toplumlardaki ekonomik ilişkileri ve kapitalistleşme sürecini ciddi bir şekilde belirlediğinin altı çizilmekte ve doğu toplumları ile Avrupa örnekleri üzerinde farklı dinlerin toplumsal ve yönetsel gerçeklikleri nasıl etkileyebildiğinin analizleri yapılmaktadır (Gundolf \& Filser, 2013, s. 177). Dolayısıyla kapitalizmin gelişim süreciyle ilişkili analizlerde din ve onun kısmen yansıması olan kültürü dikkate almamak araştırmanın eksikliğini gösterebilir.

Dini yaklaşımların ekonomik hayatı ve dolayısıyla kapitalizmin yükselişinin kaynağını oluşturduğu bilinen bir yaklaşımdır. Ancak, kapitalizmin yükselmesinde 16.yy dini dönüşümlerin büyük katkısı olduğu kabul edilse de kapitalizmin yükselme aşamasında da dini değerlerde gerileme olduğu söylenebilmektedir (Wilber, 1974, s. 257). İslam ve Hristiyanlığın karşılaştırmalı olarak modern devlet ve demokratikleşme üzerindeki etkisini inceleyen Minkenberg ise (2007), modern demokrasinin köklerinin Hristiyanlığa dayandığını delillerle ortaya koymuştur. Protestan teologların görüşlerini inceleyen bir araştırmacı ise, modern 
Protestan teologların bir taraftan liberteryenleri eleştirilerken diğer taraftan da gayri insani ve ruhsuz materyalizme karşı durduklarını ortaya koymuştur. Bu ikili kritiğin de bireysel özgürlüklerle sosyal kurumların güçlerinin dengelenmesi gerektiğini ortaya koyduğu bunun da modern dinin özü olduğu savunulmuştur (Riis, 1989).

Ayrıca demokrasinin köklerinin Hristiyanlık tarafından kültürü biçimlenen ülkelerde olduğunun teyit edilebildiği ortaya konulmuştur. Ayrıca Yunanistan'da vatandaşlığın artık Yunan Ortadoks Kilisesi üyeliğine bağlanması ve Türkiye'nin AB'ye olan üyelik sürecini açık bir şekilde etkilediğinin görülmesinin dinin bu anlamda dikkate alınması gereken bir faktör olarak ele alınması gerektiğini ortaya koyduğu ifade edilmektedir (Minkenberg, 2007). Dolayısıyla alt yapı öğeleri ile dini değerler arasında ilişki bulunduğu kabul edildiğinde bunun Türkiye şartlarında ortaya çıkmış olan yaklaşımlar çerçevesinde analizinin yapılmasında yarar olduğu açıkça görülmektedir.

Kültürel determinizm de bu kapsamda bu kapsamdaki analizlerde dikkate alınması gereken önemli bir husustur. Kültürel determinizm, fakirliğin ve az gelişmişliğin toplumların kendi inanç, tavır ve alışkanlıklarına bağlı olarak içsel bir dinamiği olduğunu ortaya koyar. Tarihsel maddeci yaklaşımlarda din ve kültür de dikkate alınmakta ancak daha çok araçsallık noktasındaki işlevsellikleri ön planda tutulmaktadır. Dolayısıyla merkezde ekonomik bölüşüm alındıktan sonra diğer her şey bölüşümü arttırmak için kullanılan araçlara dönüştürülmektedir.

Douglass North'a göre, bazı kuralların veya politikaların farklı toplumlarda uygulanmaya çalışılması durumunda farklı sonuçların gözlemlenmesi, kültürel mirasın bir parçası ve sosyal olarak aktarılan bilgilerden kaynaklanan bir takım sınırlılıkların empoze edilmesi ile açıklanabilir [North 2004:37'den aktaran (Bruce J. Perlman, 2007, s. 410)] Sosyal sermayeyi ekonomik üretimin verimliliğinin yağlayıcısı olarak dikkate alan Francis Fukuyama ise tüm paylaşılan toplumsal değerlerin sosyal sermaye üretemeyeceğini bazı değerlerin yanlış olabileceği gerçekliği ile açıklamaktadır. David Landes ise toplumların ekonomik gelişimleri incelendiğinde kültürün ekonomik performanslar arasındaki farklılığın temel etkeni olduğunun görüleceğini iddia etmiştir [Landes 2002: 584'den aktaran (Bruce J. Perlman, 2007, s. 410)]. Samuel Huntington da 1960 lı yıllara kadar her iki ülkenin birbiriyle karşılaştırılabilir benzer gelişim aşamalarını göstermiş olmalarına rağmen, neden Güney Kore’nin merkez kapitalist ülkelerle yarışabilecek duruma geldiğini ve Ghana'nın ise gelişemediğini, her iki ülkenin ulusal 
değerlerindeki farklılıklarıyla açıklanabileceklerini ortaya koymuştur [Harrison ve Huntington 2004'ten aktaran (Bruce J. Perlman, 2007, s. 410)]. Güney Kore'lilerin tasarruf, yatırım, sık1 çalışma, eğitim, organize olma ve iş disiplinine verdikleri değerlerle bezenmiş olan toplumsal kültüre sahip olmalarının, toplumsal ve ekonomik olarak gelişmelerini devam ettirmelerini sağlamış olduğu iddia edilmiştir (Bruce J. Perlman, 2007, s. 410).

\section{5. İslam Ekonomisinin Psikolojik Temelleri}

İslam ekonomi prensipleri ve gayeleri makro oldukları gibi daha çok mikro temellere dayanır ve dar daire üzerinde odaklandıkları için, insanın davranışları ve bunların kaynakları olan duygu ve düşünceleri, yani kısacası insan psikolojisi büyük önem kazanmaktadır. Kuşkusuz insan, psikolojik sağlığı ve mutluluğu ifade eden iç huzura yani ruhsal rahata sahip değilse kendi yaptığı çalışmalardan azami verimin alınması da mümkün değildir. İç huzurunun ve moralin, insan sağlı̆̆ üzerinde olduğu kadar çalışma ortamı, sosyal hayattaki münasebetlerinde ve kişisel performans üzerinde de hayati öneme sahip olduğu hususunda bütün psikologlar hemfikirdirler.

"Azalan verimler" (diminishing returns) olarak ifade edilen iktisat teorisi ilkesi de ekonomik düzlemde bu durumu ifade eden kurallaşmış bir genellemedir. Biraz değinmek gerekirse örneğin, gelir seviyesi artan, yani belli bir refah düzeyine ulaşan işçi daha az çalışmak isteyeceğinden dolayı, gelirin artması ile birlikte kişi başına düşen çalışma saati de, önce artan daha sonra azalan bir hızla artacak, fakat sonra önce azalan daha sonra da artan bir oranda azalmaya başlayacaktır. Bu durum ihtiyaçların psikolojik tatmin düzeyi veya marjinal fiziki fayda ile açıklanmaktadır. Halbuki, aşağıda da açıklanacağı üzere samimi Müslümanlar, sadece kendi kişisel çıkarları değil toplum çıkarları için ve Allah rızasını kazanmak için çalışacaklarından dolayı belli bir refah seviyesini aşsalar da yani marjinal fiziki faydaları minimumda olsa da gene maksimum verim için çalışmaya gayret edeceklerdir. Çünkü, gerçek mümin bir Müslüman için elde edilecek marjinal faydanın azalmasından çok toplumsal ve manevi yarar ön planda tutulur ki bu da psikolojik temellere dayanmaktadır. Bu hususlar, ekonomik yaşam, üretim düzeyi ve kalkınma ile yakından ilgili olduğundan ileriki bölümlerde tekrar değinilecektir.

Kuşkusuz insanın ruh hali, yaklaşım tarzı ve algıları onun çevresi ile ilgili ilişkilerini ve davranışlarını etkilemektedir. Bu husus psikolojide tartışmasız bir gerçek olarak bilinmektedir. 
İnsanın bakış açısı "nazar" ve özel amaçları "niyet” olarak isimlendirildiğinde bunların yani niyet ile nazarın ne kadar önemli etkenler olduğunu anlamak için Bediuzzman tarafindan yapılmış analizlere bakılabilir. Mesnevi-i Nuriye isimli eserinde "Ve keza nazar ile niyet, mahiyet-i eşyayı tağyir eder. Günahı sevaba, sevabı günaha kalbeder” şeklindeki ifadesi ile "Maddiyata esbab hesabıyla bakılırsa cehalettir. Allah hesabıyla olursa, marifet-i İlâhîyedir" bu anlamda değerlendirilebilir. İlk ibareye göre insanın günah görülen bazı fiilleri ibadet olabileceği gibi ibadet olan fiilleri de günah olabilir. Örneğin gösteriş anlamında olan “riyakarlık", kendisini yeterli görmek anlamında olan "ucub", kendisini daha üstün gören "kibir ve gurur" aslında birer psikolojik tuh halini göstermektedir. Bunların fillerine bulaşması durumunda ibadet ve sevap yerine günah kazanması söz konusu olmaktadır. Benzer şekilde bencillik ve şahsi menfaatini toplumun veya insanların faydasından üstün görmek de bir ruh hali olduğundan dolayı dini açıdan çok sakıncaları vardır. "kendisi için istediğini Müslüman kardeşi için istemeyen hakiki iman etmiş olamaz" şeklinde pek çok Hadis mevcuttur. Ayrıca, “insanların en hayırlısı insanlara yararı olandır" hadisi ile birlikte bakıldığında aslında toplumsal ve ekonomik pek çok faaliyet niyet ve nazarın doğru bir şekilde kullanılması durumunda ibadet hükmünde sevap kazandıracağı söylenebilir.

"İhlas" kavramı da dini bir kavram olup, samimiyet ve karşılık beklemeden Allah'ın razı olacağı davranışı sergilemek olarak tanımlanabilir. $\mathrm{Bu}$ da aslında insanın niyeti, nazarı ve yaklaşımı ile ilgili bir husustur. Çünkü şekilsel olarak aynı fiilleri yapanların eğer niyetleri farklı ise sonuçları da dini olarak değiş̧ebilmektedir. Bu hususta şu hadis büyük önemi haizdir: “insanlar helak olur, âlimler müstesna, âlimler helak olur, amel edenler müstesna, amel edenler de helak olur, ihlas sahipleri müstesna, onlar da tehlikeye dikkat etmelidir." Dolayısıyla ihlas ve samimiyet olmadan din imtihanını kazanmanın olanaklı olmadığı açıkça ortadadır. Bu hususta Bediuzzman İhlas Risalesinde şu ifadeleri kullanmaktadır:

“Ey âhiret kardeşlerim ve ey hizmet-i Kur'aniyede arkadaşlarım! Bilirsiniz ve biliniz: Bu dünyada, hususan uhrevî hizmetlerde en mühim bir esas en büyük bir kuvvet en makbul bir şefaatçi en metin bir nokta-i istinad en kısa bir tarîk-ı hakikat en makbul bir dua-yı manevî en kerametli bir vesile-i makasıd en yüksek bir haslet en safi bir ubudiyet: Ihlastır."

Dolayısıyla, ihlas, en mühim bir esas, en büyük bir kuvvet, en makbul bir şefaatçi, en metin bir 
dayanak noktası, en kısa bir hakikat yolu, en makbul bir manevî dua, en kerametli bir vesile, en yüksek bir haslet ve en safi bir ubudiyet gibi her yüksek manayı ihtiva eden çok kilit bir kavram olarak tanımlanmaktadır. "İhlas” sahibi bir Müslümanın ekonomik tercihler, tüketim kalıpları ve yatırım kararları da elbette farklı olacaktır. Ekonomik veya sosyal süreçlerde sıkıntıların yaşanması ve zorlukların meydana gelmesi durumunda kurtarıcı olarak da "ihlas" gösterilmektedir. Kısacası maddi ve manevi tüm muvaffakiyetler "ihlas" manasında mevcuttur. İnsan psikolojisini ve tatmin düzeyini olumlu yönde etkileyen esaslı bazı kavramlar vardır ki bunlar, ekonomideki üretim ve tüketim tarzı ile bölüşüm ve gelir dağılımını da belirleyecek kadar önemli hususlardır. Bu kavramlar; israf etmemek, hırs ile rızka saldırmamak ve ruhi ve bedeni zararı olan her türlü faaliyet ve tüketimden uzak durmak gibi inanç ve tatmin ile yakından ilişkili teşvik edici ve düzenleyici ilkelerdir. Örneğin; "Muhakkak ki Allah israf edenleri sevmez", "İnsanlar için ancak çalıştığının karşılı̆̆ı vardır" gibi ayetler ile "Çalışan Allah'ın sevgilisidir" gibi hadisler, "Kanaat eden aziz olur, tamahkarlık yapan zelil olur", "Ísrafta hayır yok, hayırda da israfyoktur" ve "Hırs eden hasaret eder" gibi düstur haline gelen dini vecizeler, İslam ekonomi prensiplerinin daha çok insanın yaşamını yönlendiren insan psikolojisine endekslendiğini ve insana dişardan müdahale etmekten çok insan hareketlerine yön veren duygu ve düşüncelerini ayarlamak üzerine tesis edildiğini göstermektedir.

İnsan psikolojisi ile yakından ilişkili olan bir husus da kader ve tevekkül konuları olup, bu hususlar aslında çalışma hayatını etkileyen en önemli kavramlardandır. Gerçek kader inanışı öğrenildiğinde "kadercilik anlayışı bizi geride bıraktı” şeklindeki söylemlerden vazgeçilmesi gerektiği anlaşılabilecektir. İslam'da Allah'ın geçmiş, gelecek ve hazır zamandaki bütün hadiseleri bilmesi olarak bilinen kadere iman edilir fakat kaderde yazılı olanların gerçekleşmesine yani kaza olmasına da, "kaderimizde varmış" denilerek teslim olunur ki bu da çalışma hayatını derinden etkileyen ümitsizliğin ve hüznün ilacıdır. Yoksa "nasıl olsa kaderinde neyse o olur" deyip tembellik yapmak, İslam'ın kader anlayışına aykırı olduğu gibi doğru tevekkül biçimi olarak da kabul edilmemektedir. "Mevcuda iktifa dûn-himmetliktir" (Nursi B. S., Mektubat, 1956, s. 477) denilerek eldekileri yeterli görerek çalışmadan vazgeçmek veya gayret etmeye devam etmemek himmetsizlik gibi kötü bir şekilde nitelendirilmektedir. Benzer şekilde "Ey sa'y ve ameldeki lezzet ve saadeti bilmeyen tembel insan” (Nursi B. S., Lemalar, 1655, s. 123) diye tembellik yapanlara hitaben yazılan bir risalede, çalışma ve gayret etmekte ayrı bir lezzet ve saadet bulunduğu, Allah'ın her çalışmanın ücretini onunla ilgili 
süreçteki faaliyetlerin içerisine koyduğunu kâinattan örnekler verilerek açıklanmaktadır.

Kader, Allah'ın ezeli ilminin yukardan bakar bir ayna gibi geçmiş, gelecek ve şimdiyi birden bilmesi olup, bir imtihan sırrı olarak insanın kendi iradesi ile yaptığı tercihlerde sorumluluğu esastır. Yoksa Allah'ın insan tercihlerine bağlı olmaksızın yarattı̆ğ hadiseler, kendisinin sınanması için veya insanın fiilleriyle doğrudan ilişkili olmayan afaki konularda gerçekleşmektedir ki zaten kendisini sorumlu kılmamaktadır. Günahlar ve gelecek ile ilgili konularda kadere sarılmak değil, insanın kendi tercihi söz konusu olduğundan dolayı, cüzi irade denilen tercih hakkını doğru bir şekilde kullanmak noktasından insan mesul olmaktadır. Çünkü tercih hakkının suistimali veya yanlış kullanımı söz konusu olmaktadır.

Tevekkül ise "tertib-i mukaddematta değil, terettüb-ü neticede caizdir". Yani, işin başlangıcında değil, insan gücü ve imkanlarının tükendiği noktada neticenin Allah’tan beklenmesi olan tevekkül, aynı zamanda kadere imanın bir parçasıdır. Dolayısıyla, bazılarının dediği gibi Müslümanların inanışında kalkınmaya ve ilerlemeye engel alan miskin ve tembelce bir kader inancı doğru olmayıp, varsa da cehaletin ve batıl Cebriye Mezhebinde olduğu gibi yanlış bir itikadın eseri olabilir.

İsraf konusu da insan psikolojisi ile çok yakından alakası olan diğer bir konudur. Bediuzzaman, Lem'alar isimli eserinde ekonomik sorunların çoğunun israftan, hırstan, kanaatsizlikten ileri geldiğini ileri sürmüştür. Bu konuya biraz daha yakından değinmek gerekirse; israfın olduğu bir ekonomide kaynakların optimum dağılımı ve tam istihdamı mümkün değildir. Örneğin olaya mikro-ekonomi kapsamında yaklaşıldığında; kendi imkanlarını rasyonel olarak kullanmayıp israf edenler, sonuçta sıkıntıya düşüp kamu imkanlarından yararlanma veya beleşten geçinme yollarında bekleyeceklerdir ki, bu durum sosyal ve ekonomik politikalar yoluyla kamu harcamalarının artmasına ve de kamu kaynakların israf olmasına yol açacaktır (Nursi B. S., Lemalar, 1655).

Kaynağının büyük bir kısmını israftan alan "hırs" veya "ihtiras" da psikolojik ve bunun bir sonucu olarak ekonomik sıkıntılara yol açan başka bir faktördür. Çünkü, hırs ile hareket edenler de kuşkusuz, ekonomik sonuçların hemen eline geçmesini isteyerek, sabırsızlıkla belli bir sisteme göre hareketlerini ayarlayamayacaklarından dolayı, çabucak kanaatsizliğe düşüp, çalışmak ve gayret etmekten vazgeçeceklerdir. Bu husus, toplumda ümitsizliği doğuran bir etken olduğundan dolayı, neticede hem devlet kapısına gözler dikilir hem de her kes kolay 
kazanç yollarını aramaya başlar ki, nihayet, yolsuzluklar ve huzursuzluklar ile suç işleme oranlarında artış görülür. Bunların sonucunda da iktisadi büyüme ve kalkınma veya refah düzeyinin artmasını beklemek fazla iyimserlik olarak nitelendirilebilir.

Aciz yavrular, ağaçlar ve zekavetsiz balıklar ile zeki tilkiler ve vahşi hayvanların ve onlara verilen rızklarının karşılaştırılmasıyla, rızkın imkanlara ve yetenekten ziyade muhtaçlık ve kanaat derecesine göre daha kolay ve fazlaca verildiği görülür. Aptal balıklar, meyve kurtları ve aciz yavruların semizliği ve harikulade bir şekilde rızklarının kendilerine koşturulması ile hareketsiz ağaçların rızklarının ayakları altında verilmesine kadar pek çok olağan karşılanan hadiseye dikkat edildiğinde bu hususun ne kadar açık ve aşikar olduğu anlaşılır. Bunun yanı sıra, hırsın, kanaatsizliğge ve ekonomik olarak zarara uğratması yanında aynı zamanda ihlası da kırmasına işaret olarak Bediuzzaman, hırs ile hareket etmenin hem dünya hayatını hem de ahiret hayatını ihlassızlıkla tehlikeye soktuğunu belirtmiştir. Ancak, neticeye odaklanmadan belli bir plana göre çalışarak neticeye kanaat ile daha çok çalışabilecek olması da ekonomik anlamda kanaatin önemini ve başarının bir yolunu göstermektedir.

Kuşkusuz insan psikolojisi ve ruh hali, aslında tesiri altında bulunduğu felsefelerin, kabullerin ve inanışların birer yansıması şekline tezahür etmektedir. Bu nedenle de Bediuzzaman'ın felsefe öğrencisi ile Kuran talebesinin insanın şahsi hayatının terbiyesine verdiği dersi karşılaştırırken felsefe talebesi için şu şekilde ifade kullanmaktadır:

"Felsefenin hâlis bir tilmizi, bir firavundur. Fakat menfaati için en hasis şeye ibadet eden bir firavun-u zelildir. Her menfaatli şeyi kendine "Rab" tanır. Hem o dinsiz şakird, mütemerrid ve muanniddir. Fakat bir lezzet için nihayet zilleti kabul eden miskin bir mütemerriddir. Şeytan gibi şahısların, bir menfaat-ı hasise için ayağını öpmekle zillet gösterir denî bir muanniddir. Hem o dinsiz şakird, cebbar bir mă̆rurdur. Fakat kalbinde nokta-i istinad bulmadığ için zâtında gayet acz ile âciz bir cebbar-ı hodfüruştur. Hem o şakird, menfaatperest hodendiştir ki; gaye-i himmeti, nefs ve batnın ve fercin hevesatını tatmin ve menfaat-ı şahsiyesini, bazı menfaat-ı kavmiye içinde arayan dessas bir hodgâmdır” (Nursi B. S., Sözler, 1960, s. 132).

İfadelerden de anlaşılacağı üzere, dinsiz felsefeden ders alan bir öğrencinin büyüklenme, paranoya ve kendisini sahip olmadığı özelliklerle bezenmiş görme eğilimi içerisine girerek firavunluk derecesine çıkabilme potansiyeli göstermektedir. Ancak aynı zamanda 
menfaatperest olarak kendi menfaati olan her şeyi büyük görme, bükemediği eli öpme, kendisine verene karşı zillete düşerek miskinleşme psikolojisini de birlikte yaşayabilmektedir. Hem inatçılık yapar ancak bu inatçılığı lezzet ve aşağılık menfaatleri elde edebilme noktasında sarf ettiğinden her türlü melaneti yapabilir bir kişilik ve ruh hali gösterebilmektedir. Cebbar ve mağrur olarak kendisinden aşağı olanları ezme, tahakküm etme ve düşene vurma gibi merhamet ve şefkatle uyumlu olmayan bir ruh hali taşırken kalbinde bir dayanağı olmadığından aslında aciz olduğu halde kendisini büyük gösterme çabası içerisinde hodfurüş bir psikoloji içerisine girebilmektedir. Sadece kendisi için endişe ettiği ve menfaatlerini karışmama noktasında strese girdiğinden dolayı tek amacı nefsinin, midesinin ve cinsi arzularının tatmin edilmesi noktasında büyük gayret içerisindeyken aynı zamanda ırkçılık ve kavimcilik gibi duygulara da sahip olabilmekte ve 1rkçılığı kendi menfaati için kullanabilecek düzeyde ayrılıkçı, şüpheci ve fitneci bir yapı göstermektedir. Bu vasıfların tam tersini taşıyan Kuran talebesi için de aşağıdaki ifadeler kullanılmaktadır:

“Amma hikmet-i Kur'anın hâlis tilmizi ise; bir abd'dir. Fakat a'zam-ı mahlukata da ibadete tenezzül etmez. Hem cennet gibi a'zam-ı menfaat olan bir şeyi, gaye-i ibadet kabul etmez bir abd-i azizdir. Hem hakikî tilmizi mütevazidir; selim, halîmdir. Fakat Fâtırının gayrına, daire-i izni haricinde ihtiyarıyla tezellüle tenezzül etmez. Hem fakir ve zaîftir, fakr ve za'finı bilir. Fakat onun Mâlik-i Kerim'i, ona iddihar ettiği uhrevî servet ile müstağnidir ve Seyyidinin nihayetsiz kudretine istinad ettiği için kavîdir. Hem yalnız livechillah, rıza-i Ilahî için, fazilet için amel eder, çalışır... Işste iki hikmetin verdiği terbiye, iki tilmizin müvazenesiyle anlaşılır” (Nursi B. S., Sözler, 1960, s. 132).

Kuran hikmetinden ders alan birisi de bir kul olarak kendisini bilir ancak en büyük mahlûklara karşı boyun eğmez ve onları kendisinden büyük tanımayacak derecede yüksek ruhlu bir psikoloji içerisindedir. Aynı zamanda cennet gibi en büyük sayılacak nimet ve menfaatleri bile kendisine ibadet gayesi yapmayacak ölçüde azizdir. Hem mütevazi, halim, selim ve alçak gönüllü iken aynı zamanda Rabbisinin dışında kimseye Onun izni haricindekilere isteyerek asla boyun eğmez ve tenezzül etmez. Kendisine verilen hiçbir şeye hakiki sahip olmadığını gördüğünden ve eline emanet olarak verilen her şeyin bir gün kendisinden alınacağını bildiğinden dolayı Allah’a karşı fakir olduğunun farkında, mikroptan göktaşlarına kadar pek çok şeyin kendisini tehdit ettiğini bildiğinden dolayı kendi nefsinde devamlı olacak bir güce sahip olmadığını bildiğinden aciz olduğunun şuurunda olduğu halde Allah dışında her şeyin 
kendisi gibi olduğunu düşündüğünden onun için saklanan hazine ve servet ile zengin bir his taşır ve Allah'ın nihayetsiz kuvvetine dayanarak ondan yardım beklediği için de kendisini güçlü bilir. Sadece Allah rızası, fazilet ve erdem için çalıştığından dolayı sonuçları elde etmese bile ümitsizliğe ve depresyona girmeyecek bir potansiyel gösterir. Bu nedenle de kalkınma ve ekonomik gelişme için Kuran'ın hikmetinden ders alan birisi yılmadan çalıştığından dolayı dinsiz felsefeden ders alanlara göre toplumsal olarak daha yararlı bir nitelik gösterir.

Eğer tahkiki iman elde edilmezse her şeyin tesadüfü olduğu ve her sevdiklerinden ayrılabileceği, ölebileceği ve kendisine acıyarak nihayetsiz ihtiyaçlarına nihayetsiz bir rahmet, ilim ve kudretin yardım edemeyeceği gibi ruh haline kapılmışsa insanın dünyada büyük serveti, makamı ve hazineleri de olsa hayatta gerçek mutluluk ve saadetin elde edilemeyeceği şu şekilde ifade edilmektedir:

"Hayat ise, ĕger iman olmazsa veyahut isyan ile o iman tesir etmezse; hayat, zahirî ve kısacık bir zevk ve lezzetle beraber, binler derece o zevk ve lezzetten ziyade elemler, hüzünler, kederler verir. Çünki insanda akıl ve fikir olduğu için, hayvanın aksine olarak hazır zamanla beraber geçmiş ve gelecek zamanlarla da fitraten alâkadardır. $O$ zamanlardan dahi hem elem, hem lezzet alabilir. Hayvan ise, fikri olmadiğ için, hazır lezzetini, geçmişten gelen hüzünler ve gelecekten gelen korkular, endişeler bozmuyor. Insan ise, ĕger dalalet ve gaflete düşmüş ise, hazır lezzetine geçmişten gelen hüzünler ve gelecekten gelen endişeler o cüz'îlezzeti cidden acılaştırıyor, bozuyor. Hususan gayrl meşru ise, bütün bütün zehirli bir bal hükmündedir. Demek hayvandan yüz derece, lezzet-i hayat noktasında aşağı düşer. Belki ehl-i dalaletin ve gafletin hayatı, belki vücudu, belki kâinatı; bulunduğu gündür. Bütün geçmiş zaman ve kâinatlar, onun dalaleti noktasında madumdur, ölmüş̧ür. Akıl alâkadarlı̆̆ı ile ona zulmetler, karanlıklar veriyor. Gelecek zamanlar ise, itikadsızlı̆̆l cihetiyle yine madumdur. Ve ademle hasıl olan ebedî firaklar, mütemadiyen onun fikir yoluyla hayatına zulmetler veriyorlar. Ĕger iman hayata hayat olsa; o vakit hem geçmiş, hem gelecek zamanlar imanın nuruyla ışıklanır ve vücud bulur. Zaman-ı hazır gibi ruh ve kalbine iman noktasında ulvî ve manevî ezvakı ve envâr-ı vücudiyeyi veriyor" (Nursi B. S., Sözler, 1960, s. 145).

Bediuzzaman, Münazarat isimli eserinde, "zindan-ı atalete düşmemizin sebepleri nelerdir?" 
sualine konu ile ilgili ayet ve hadislerdeki emir ve tavsiyelere dayanan, özellikle insan psikolojisi konularına ağırlık vererek insanın psikolojik ruh halinin ne derece belirleyici olduğunu ortaya koyması açısından dikkate değer olan, psikolojik olarak insanı mükemmelle götürebilecek ve dünya hayatında terakkiye sevk edecek mahiyette cevaplar vermiştir. Kişisel ve toplumsal gelişimin önünde bir takım psikolojik ve ruhi olumsuzlukların engel oluşturduğu ve bunların İslami perspektifle nasıl ortadan kaldırılabildiğini gösterecek şekilde verilen cevaplar maddeler halinde şu şekilde özetlenebilir:

1. Hayat bir faaliyet ve harekettir. Şevk ise bineğidir. Himmeti ve çalışmadaki şevki kıran yeis ve ümitsizliğe karşı “ümidinizi kesmeyiniz”(Zümer Suresi,53) silahı kullanılmalıdır. Çünkü hayatı canlandıran ve duygu katarak renklendiren şey şevk yani motivasyon ise bunun da ümitsizlik ve yeis denilen içe kapanma ve hareketsizleşme hali insanın ruhi yansıması ve terakkisi için gerekli olan psikolojik daralma ve depresyon durumlarıdır ki bunlar ansak sonsuz rahmet sahibi, tükenmez kudret sahibi ve sınırsız ilim sahibi Allah'a olan itimat ve ümit ile etkin bir şekilde mücadele edilebileceği söylenebilir.

2. Çekişmesiz olan hakkın hizmetinin yerini zapt eden meyl-i tefevvüke (üstünlük kompleksi) ne karşı “Allah için olunuz" hakikati ile karşılık vermelidir. Çünkü Allah rızası kalktıktan sonra insan psikolojisinde bireysellik ve egoizm gibi insana ve topluma zarar veren duygular yeşerir. Başkalarının kendisini geçmesi veya göreceli olarak başkalarından daha kötü durumda olma bilinci insanın şevkini kırdığından başkalarının geride kalması veya sadece kendisine yarar sağlayan yollara düşülmesi de ortak çalışma kültürünü, sinerjiyi ve ekip hareketini olumsuz etkiler. Bu nedenle de üstünlük kompleksine karşı insanın kendisini tanıması, gayesini ve hakikatini anlamasına vesilen olan "lillah" hakikatinin anlaşılması ve içselleştirilmesi gerekir.

3. Sonra da, silsile halinde teenni ile yapılması gereken işlerde acelecilik hastalı ̆̆ himmetin ayağını kırarsa "Sabırlı olun, sabır yarışında düşmanlarınızı geride bırakın" (Al-i İmran Suresi,200) emri ile aceleciliğin kökü kurutulmalıdır. Çünkü acelecilik ile insan sonuçları birden elde etmeye ve çalışmasının neticesi olan çıktıları çabucak görmek isteyen bir psikolojik ruh haline girer. Bu da sabırsızlığı sonuç verdiği için bir iş için gerekli olan tertip ve kategorik sıraların atlanmasına ve bazı eksikliklerin meydana gelmesine yol açar. Bu da ancak inançla ve "sabırlı olun" gibi emirlere uymakla elde edilebilir.

4. Sonra, insanların gayretlerini ve enerjilerini dağıtan ferdiyetçilik ortaya çıktığında ona karşı "İnsanların en hayırlısı, insanlara en çok faydalı olanıdır" hadisini rehber ederek mukabele 
etmelidir. Çünkü ferdiyetçilik belirli bir noktaya varıldıktan sonra şevk ve gayretle çalışmanın önünü kesen bir ruh halini gösterir. Ya da kendi bir birimlik faydasını toplumun yüz birimlik faydasına değişmeyen acımasız ve merhametsiz bir psikolojiye girmeye yol açabilir. Bu da toplumsal kalkınma ve sosyal bilinç açısından olumsuz bir psikoloji olarak nitelendirilebilir. $\mathrm{Bu}$ nedenle de insanlığın yararına çalışmayı bir ibadet çeklinde görme anlayışı ekonomik faaliyetlerin ve iktisadi kalkınmanın da motoru olabilecek nitelik arz etmektedir.

5. Daha sonra başkalarının "memleketi kurtarmak sana mı kaldı" dercesine tembellik veya hazır yiyicilik yapanların kötü örnek olmasıyla gayretin ve çalışmanın gerilemesi karşısında "siz doğru yolda oldukça sapmış olanlar size zarar vermez" (Maide Suresi,105) düsturu rehber alınmalıdır. Çünkü nemelazımcılık ve kötü örneklerin yaygın bir şekilde örnek alınması kişisel gelişim ve toplumsal yapının uyumluluğu açısından olumsuz bir psikoloji oluşmasına neden olur. Bu hastalıktan da ancak ilahi emirlerin rehber alınmasıyla kurtulabilmek olanaklıdır. Başkalarının ne düşündüğü veya sapkınlığı doğru yolda gidenlere bir zarar vermediği şeklindeki mantıksal gerçekliğin vahiy ile desteklenmesi psikolojik tatmin ve iç huzuru sağlayabilmektedir.

6. Sonra, meşakkatin anası ve umum rezaletin yuvası olan meyli-rahatın (tembelliğin) himmeti ve gayreti hapsetmesine karşı da "İnsan için ancak çalıştığının karşılığı vardır" (Necm Suresi,39) ayetindeki yüksek düstur rehber alınarak çalışma ve gayreti bir ibadet ve dua olarak görmeli ve içerisinde saklı olan lezzet ve saadeti keşfetmelidir. Çünkü bazen insan çalıştığının karşılığını hemen alamayabilirse de çalıştı̆̆ının karşılığının istenilen şekilde olmasa bile farklı bir surette mutlaka verileceğine olan inanç veya birilerinin çalışmadan haksızlıklarla bir takım kazanımlar elde etmesine karşı bozulan insan psikolojisinin herkesin mutlaka günün birinde müstahakkını göreceğine olan iman tembelliğin yaygınlaşmasının önünde aşılmaz bir engel oluşturabilmektedir.

Bediüzzaman, Osmanlı'nın yıkılmasından önce yazdığı “Hutbe-i Şamiye” isimli eserinde gene psikolojik ve mikro temelli bir yaklaşımla, geri kalmışlığın nedenleri olarak yukarıda bahsedilen hususlar üzerinde duruştur. Özetle; toplum içinde ümitsizliğin yaygınlaşması, doğruluğun kalkarak insanlar arasında yalancılık ve düşmanlığın yerleşmesi, bireysel şuurla kendisini üstün görmek, rahatını düşünme ve işi başkasına bırakarak kaytarmak düşüncelerinin planlı, tertipli ve kolektif çalışma şuur ve ortamını ve dolayısıyla çalışmanın neticeleri olan kalkınma ve refahı kaybetmeye neden olduğunu iddia etmiştir. Esaslı noktaları irdelendiğinde, 
toplumdaki emniyet ve itimadın arttırılması için "doğruluk", ümitsizlik ve kanaatsizliğe kapılmayarak çalışmanın her aşamada devam etmesi için "ümitli olmak”, rahat meylini terk etmek ve bireysel çıkarcılığın bırakılmasıyla "toplumsal yarar"ın gözetilmesi hususları toplumsal refah ve dolayısıyla ekonomik istikrar için göze çarpan çok önemli hususlardır. (Nursi B. S., 1950)

\section{Sonuç}

Ekonomi insan tercihlerine göre şekil almaktadır. Tüketici olarak hane halkının üretici, istihdam edici ve vergi veren olarak yatırımcıların harcama alanları ve miktarları ile ilgili tercihleri ekonomideki sorunları ve çözümleri belirleyen davranışlarına göre makro ve mikro ekonomik değişkeler etkilenmektedir. Her dinde toplumsal yaşamla ilgili, diğer insanlar ve doğa ile olan ilişkileri düzenleyen hükümler az çok mevcuttur. Bu anlamda dindar insanların da iktisadi hayattaki davranışları değişebileceğinden dolayı üretim, tüketim ve yatırım ile ilgili tercihleri dini değerlere göre değişim gösterebilecektir.

Sürdürülebilir ekonomik kalkınma aslında İslam'da da mevcuttur. Ancak bunlar politika ve kurumlar üzerinden değil, insan davranışlarını etkileyen iman ve bunun gereği olarak uygulanması gereken etik değer ve ilkelerin tesis edilmesiyle ilişkilidir (Ansari, Jamal, \& Oseni, 2012, s. 618). Şeriat-1 fitriye diye tabir edilen Allah'ın yarattığı tabiat kanunlarına uyumlu davranarak gelecek nesillere, tabii düzene ve diğer varlıklara zarar vermeksizin ondan en iyi bir şekilde yararlanmak maddi politika tedbirlerle tek başına olanaklı olmayıp, ruhi ve psikolojik gelişim gerektiren aç gözlü olmamak, acele etmeden sabredebilmek, aşırılığa gitmeden mütevazi olmak, dengeli davranmak, yıkıcı rekabet yapmadan işbirliğinde bulunmak ve adalet ile eşitliği esas alıp yolsuzluğa tenezzül etmemek gerekir (Hasan, 2006, s. 14).

Yapılan analizler sonucunda araştırma sorularımız şu şekilde cevaplanabilmiştir:

\section{1. İslam dininin ilkeleri insan davranışlarını yönlendirici olarak psikolojik açıdan analiz} edilebilir mi?

İslam dini, insanı muhatap almaktadır. Dolayısıyla herhangi bir kurumsal yapı ve politik düzeni kastetmediğinden dolayı insan davranışlarının dünyevileşmesi değil dünyadaki imkânları kullanarak kısa olan dünya hayatının ebedi sonuçlar verecek şekilde uhrevileştirilmesini hedeflemektedir. Bu nedenle de dünya hayatının imarı ve güzelleştirilmesinden çok insanın kendisini, mahlûkları ve dolayısıyla yaratıcısını tanımaya çalışmak ve onun memnun olacağı 
davranışlarda bulunarak ona ulaşmanın temellerini vermektedir. Bu temeller de tüm negatif değer ve davranışları terk edip tüm insanlığın yararına olan düşünce ve davranışlara girmek esasına dayandığından dolayı insanın dünya hayatının da güzelleşmesine ve diğer insanlar ve topluluklarla olan ilişkilerinde olumlu olmayı sağlayabilecek potansiyeldedir. Salt anlamda sürekli iktisadi büyümeyi, servetine servet katmayı ve başkalarının zararına menfaatini takip etmeyi istemediğinden dolayı insan bilincinin oluşması, kabullerinin yapılandırılması ve inancının içselleştirilmesini gerektirdiğinden dolayı psikolojinin alanına girmektedir. $\mathrm{Bu}$ nedenle de İslami ilkelerin psikolojik metotlarla incelemeye alınması gerekli ve olanaklıdır.

2. Türkiye'de ortaya çıkan çă̆daş bir eser olması açısından Risale-i Nur tefsiri İslam ekonomisinin psikolojik temellerini ortaya koyabilme açısından referans alınabilir mi?

Evet. Dini ilkelerin toplumsal hayata yansıtılmasını iman-ı tahkik denilen gerçek ve içselleştirilmiş inanç kavramıyla ortaya koymakta ve bunu ispatlamaktadır. Müslüman ülkelerdeki başarısızlıklar ve gerilemeyi de gene gerçek imana sahip olmamaktan dolayı İslami değerlerin kişisel ve dolayısıyla toplumsal hayata yansıtılmamasına bağlamıştır. Aynı zamanda gerçek imanın Dünya hayatında da bir Cennet çekirdeğini taşıdığı ve dolayısıyla "hakiki zevk, elemsiz lezzet, kedersiz sevinç ve hayattaki saadetin iman ile mümkün olduğu" nu iddia ederek mantıksal analizlerle insan psikolojisine uygun olmayan dünyevi sistemlerin sürdürülebilir bir şekilde insan saadet ve mutluluğunu sağlayamayacağını savunmuştur.

“Ey zevk ve lezzete mübtela insan! Ben yetmişbeş yaşımda binler tecrübelerle ve hüccetlerle ve hâdiselerle aynelyakîn bildim ki: Hakikî zevk ve elemsiz lezzet ve kedersiz sevinç ve hayattaki saadet yalnız imandadır ve iman hakikatleri dairesinde bulunur. Yoksa dünyevî bir lezzette çok elemler var. Bir üzüm tanesini yedirir, on tokat vurur gibi hayatın lezzetini kaçırır" (Nursi B. S., Sözler, 1960, s. 150)

İslam'da esas olan tahkiki bir imanla Dünya hayatının geçici bir imtihan yeri olduğuna olan inancın mantıksal ve duygusal bir gereği olarak; Allah'ın razı olacağı kendi emeğiyle çalışma, muhtaçlara maddi ve manevi yardımda bulunmak, borç vermek, güvenmek ve güveni tesis etmek, zekât vermek, faizden uzak durmak ve hayırlı işlerde harcama yapma sonucunda meydana gelecek davranış ve etkinlikler ekonomik hayatın da temel dinamiklerini oluşturacaktır. İslam'ın dolaylı olarak getirdiği ekonomi prensipleri, daha çok psikolojik temellere dayandığından dolayı, bireyin vicdanına etki etmeyen hiçbir idari nitelikteki önlemin, 
hukuk ve kamu gücüne dayanması durumunda bile tam ve kalıcı olarak tesirli olamayacağı ve olumlu sonuçlar doğuramayacağı ana fikrine dayanmaktadır. Bu gerçek, İslam'a has bir hususiyet ve orijinalliği ortaya koymaktadır. Ayrıca, uygulanmakta olan bütün iktisadi düşünce sistemlerinin, doğurduğu olumsuz sonuçlarıyla istenilen neticeyi halen veremeyerek sürekli revizyonlar ve değişimlere mecbur kalmaları, zamanla gerçeklere yaklaşacağı sinyallerini vermekte ve İslam'ın esas kabul ettiği anlayışı benimsemeyi mecburiyet haline getirebileceğini hissettirmektedir.

Risale-i Nur, en temel esaslarından birisinin nefsin arzularına kapılmadan onu ateşe atacak davranış ve hallere girme taleplerine ona acıyarak sakındırmak olduğu söylenebilir. Aklın mideye, ruhun bedene ve kalbin de nefse hâkim olması durumunda lezzetin şükür için takip edilebileceğini ilkesel olarak ortaya koymaktadır. Ayrıca nefsin arzularına uymamamın maddi ve manevi kalkınmayı doğuracağını da zımni olarak ifade eder. Hz. Süleyman'ın havada uçmasında şu şekilde bir mesaj olduğu ifade edilmektedir. "Ey insan! Bir abdim, heva-i nefsini terk ettiği için havaya bindirdim. Siz de nefsin tenbelliğini bırakıp bazı kavanin-i âdetimden güzelce istifade etseniz, siz de binebilirsiniz." Dolayısıla, asıl hareket noktasında insanın kendi iç psikolojisindeki nefsine, boş arzularına tabi olmadan onun sahibinin emri ve rızası dairesinde hareket etmeyi içi âleminde kabullenmek ve yaşamak maddi ve manevi kalkınmanın özünü oluşturmaktadır.

\section{KAYNAKÇA}

Ansari, A. H., Jamal, P., \& Oseni, U. A. (2012). Sustainable Development: Islamic Dimension with Special Reference to Conservation of the Environment. Advances in Natural and Applied Sciences, 607-619.

Ansari, M. (1994). İslamic Perspectives on Sustainable Development. The American Journal of Islamic Studies, 394-402.

Aström, Z. H. (2011). Paradigm Shift for Sustainable Development: The Contribution of Islamic Economics. Journal of Economic and Social Studies, 73-84.

Branco, M. C. (2007). Family, Religion and Economic Performance: A Critique of Cultural Determinism. Review of Social Economy, Vol. Lxv, No. 4, December, 407-424. 
Bruce J. Perlman, G. G. (2007). Cultural Determinism versus Administrative Logic: Asian Values and Administrative Reform in Kazakhstan and Uzbekistan. International Journal of Public Administration, Volume 30, Issue 12-14, 1327-1342.

Gundolf, K., \& Filser, M. ( 2013). Management Research and Religion: A Citation Analysis. Journal of Business Ethics, January 1,, 177-185.

Hasan, Z. (2006). Sustainable Development from an Islamic Perspective: Meaning, Implications, and Policy Concerns . Islamic Economics, Vol. 19, 3-18.

Hill, L. E. (1989). Cultural Determinism or Emergent Evolotion: An Analysis of the Controversy Between Clarenve Ayres and David Miller. Journal of Economik Issues, Vol. XXIII, No. 2, 465-471.

Koehler, B. (2011). The Economist Mohammed Ibn Abdullah (570 - 632). Economic Affairs, 109-114.

Marsuki, M. Z. (2009). Religious Agendas Towards Sustainable Development: An Islamic Perspective. Malaysian Journal of Science and Technology Studies, 22-39.

Minkenberg, M. (2007). Democracy and Religion: Theoretical and Empirical Observations on the Relationship between Christianity, Islam and Liberal Democracy. Journal of Ethnic and Migration Studies, Vol. 33, No. 6, August, 887-909.

Mirakhor, A. (2014). The Starry Heavens Above and the Moral Law Within: On the Flatness of Economics. Econ Journal Watch, 186-193.

Nakvi, N. H. (1985). Ekonomi ve Ahlak. İstanbul: İnsan Yayınları.

Nienhaus, V. (2013). Method and Substance of Islamic Economics: Moving Where? Islamic Economics, 169-202.

Nursi, B. S. (1655). Lemalar. İstanbul: Envar Neşriyat.

Nursi, B. S. (1950). Hutbe-i Şamiye. İstanbul: Envar Neşriyat.

Nursi, B. S. (1956). Mektubat. İstanbul: Envar Neşriyat.

Nursi, B. S. (1960). Sözler. İstanbul: Envar Neşriyat.

Nursi, B. S. (1993). Münazarat. İstanbul: Envar Neşriyat. 
Riis, O. (1989). The Role of Religion in Legitimating the Modern Structuration of Society. Acta Sociologia, 137153.

Steigerwald, D. (2005). Our New Cultural Determinizm. Society, January 1, 71-75.

Wight, J. B. (2014). Economics within a Pluralist Ethical Tradition. Review of Social Economy, Volume 72, Issue 4, 417-435.

Wilber, C. K. (1974). The 'New' Economic History Re-examined: R. H. Tawney on the Origins of Capitalism. American Journal of Economics \& Sociology, July 1, , 249-258.

Zaman, A. (2012). Crisis in Islamic Economics: Diagnosis and Prescriptions. Islamic Econ, n., Vol. 25 No. 1, 143-166. 